Part of Journal of Research of the National Bureau of Standards, Volume 27, July 1941

\title{
ENZYMATIC HYDROLYSIS OF DISACCHARIDES AND HALOGENOSALICINS
}

\author{
By William Ward Pigman
}

\begin{abstract}
In agreement with the Weidenhagen theory, the enzymes of almond emulsin hydrolyze all of the disaccharides with $\beta$-glucosidic linkages which have thus far been tried. Measurements of rate of hydrolysis are reported for the first time for gentiobiose, 4-glucosidomannose, and lactositol, and comparable data are assembled for other disaccharides. It is shown that very small changes in the configuration or structure of the aglucon sugar have a large influence on the rate of enzymatic hydrolysis. This influence is explained on the basis that two areas of the enzyme are involved is the adsorption of the disaccharides by the enzyme and that the component nonosaccharide residues are adsorbed separately on the two areas of the enzyme.

Rates of enzymatic hydrolysis under the standard conditions of Helferich are reported for the $p$-chloro-, bromo-, and iodosalicins. It is shown that the introduction of a halogen in the para position of the salicin aglucon reduces the rate of hydrolysis to less than one-third of the salicin value. While the three halogenosalicins do not differ greatly in their rate of hydrolysis, their relative ease of enzymatic splitting is iodo- $>$ bromo- $>$ chloro-.
\end{abstract}

\section{CONTENTS}

I. Introduction

II. Discussion of results

III. Experimental procedure

1. Substrates and substrate solutions

2. Enzyme solutions $\ldots$

3. Rate of hydrolysis measurements

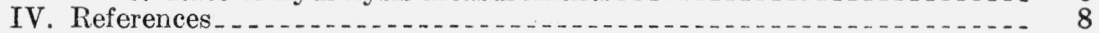

\section{INTRODUCTION}

The disaccharides are special types of glycosides for which the aglucon group is a sugar rather than a phenol or alcohol. According to the Weidenhagen theory $[1],{ }^{1}$ an enzyme which hydrolyzes a glycoside (e. g., a glucoside) should also hydrolyze disaccharides with the same configuration for the glycosidic linkage (alpha or beta) and with the same sugar (e. g., glucose) for the glycosyl portion of the molecule. In a previous paper [2], the results of a study of the action of almond emulsin on the synthetic disaccharides neolactose (4- $\beta$ galactosido- $d$-altrose) and lactulose (4- $\beta$-galactosido- $d$-fructose) were reported, and evidence was presented that the same enzyme ( $\beta$ galactosidase) is responsible for the hydrolysis of these disaccharides

\footnotetext{
1 Figures in brackets indicate the literature references at the end of this paper.
} 
and for that of lactose. The earlier work of Helferich, Gootz, and Sparmberg [3] indicated that $\beta$-galactosidase hydrolyzes lactose as well as the $\beta$-galactosides and that $\beta$-glucosidase hydrolyzes cellobiose (4- $\beta$-glucosido- $d$-glucose) and the $\beta$-glucosides. More recently, Richtmyer and Hudson [4] have measured the rate of hydrolysis of celtrobiose (4- $\beta$-glucosido- $d$-altrose), and it would seem probable that the hydrolysis of this disaccharide also is brought about by $\beta$-glucosidase.

As it seemed desirable to extend the measurements to other disaccharides with beta linkages, the hydrolysis of gentiobiose (6- $\beta$ glucosido- $d$-glucose) and 4 - $\beta$-glucosido- $d$-mannose was investigated. Although these disaccharides are known to be hydrolyzable by the enzymes of almond emulsin, the earlier measurements were not carried out under conditions comparable to those used for the previously mentioned disaccharides. Through the courtesy of M. L. Wolfrom, who provided the material for the investigation, it has been possible to investigate the enzymatic hydrolysis of a derivative of lactose, lactositol (4- $\beta$-glucosido- $d$-sorbitol). This compound is similar in structure to lactobionic acid, the enzymatic splitting of which has been reported by Helferich, Pigman, and Isbell [5], and differs from the lactobionic acid only in having a primary alcoholic group instead of a carboxyl group. The present investigation also includes the results of a study of the rate of enzymatic hydrolysis of the $p$-iodo-, bromo- and chlorosalicins. The preparation and optical rotation of these substances were previously reported by D. H. Brauns [6], who very generously made these substituted salicins, as well as several disaccharides, available for this investigation. These halogenosalicins are apparently the first aromatic glycosides to be investigated which contain halogen atoms in the aglucon. The enzymatic studies of the substances included in this investigation, in conjunction with the earlier obtained results, make it possible to investigate the effect of changes in the configuration and structure of the aglucon on the enzymatic action and to test further the validity of the Weidenhagen concept.

\section{DISCUSSION OF RESULTS}

In table 1 are summarized the results obtained for the disaccharides and derivatives. The first group of disaccharides, as previously mentioned, may be considered as $\beta$-glucosides in which the aglucon is a second hexose molecule. The second group of compounds are, similarly, $\beta$-galactosides in which the aglucon is a sugar or sugar derivative.

The relative ease of hydrolysis of the various substances is indicated by a quantity which has been called the "enzyme efficiency" (EE). This quantity is a function of the velocity constant for fixed conditions of substrate concentrations $(0.052 \mathrm{M})$, pH $(5.0)$, temperature $\left(30^{\circ} \mathrm{C}\right)$, and enzyme concentration. Helferich, who originated this method of expression of ease of hydrolyzability, calls this quantity the "Wertigkeit."

All of the compounds listed in table 1 are split by almond emulsin, in agreement with the Weidenhagen theory. All members of the first group of compounds probably are hydrolyzed by the same $\beta$-glucosidase and the members of the second group by the same $\beta$-galactosidase. 
TABLE 1.-Hydrolysis of disaccharides by enzymes of almond emulsin (Rohferment)

\begin{tabular}{|c|c|c|c|c|}
\hline Disaccharide or derivative & Aglucon & $\begin{array}{l}\text { Point of } \\
\text { attach- } \\
\text { ment in } \\
\text { aglucon }\end{array}$ & $\begin{array}{c}\text { Enzyme } \\
\text { efficiency } \\
(E E) \times 10^{3}\end{array}$ & $\begin{array}{l}\text { Refer- } \\
\text { ence }\end{array}$ \\
\hline
\end{tabular}

$\beta$-GLUCOSIDES

\begin{tabular}{|c|c|c|c|c|}
\hline $\begin{array}{l}\text { Cellobiose } \\
\text { Gentiobiose } \\
\text { 4. } \beta \text {-Glucosidomannose } \\
\text { Celtrobiose }\end{array}$ & $\begin{array}{l}d \text {-Glucose } \\
d \text {-Mannose } \\
d \text {-Altrose }\end{array}$ & $\begin{array}{l}4 \\
6 \\
4 \\
4\end{array}$ & $\begin{array}{r}\cdot 159,180 \\
c 75 \\
c 2.3 \\
a(23)\end{array}$ & {$[8]$} \\
\hline
\end{tabular}

$\beta$-GALACTOSIDES

\begin{tabular}{|c|c|c|c|c|}
\hline $\begin{array}{l}\text { Lactose } \\
\text { Lactulose } \\
\text { Neolactose } \\
\text { Lactobionic acid } \\
\text { Lactositol }\end{array}$ & $\begin{array}{l}d \text {-Glucose } \\
d \text {-Fructose } \\
d \text {-Altrose } \\
d \text {-Gluconic acid } \\
d \text {-Sorbitol }\end{array}$ & $\begin{array}{l}4 \\
4 \\
4 \\
4 \\
4\end{array}$ & $\begin{array}{r}\cdot 11.2,11.4 \\
b(14) \\
b(2.8) \\
0.41 \\
c .84\end{array}$ & $\begin{array}{l}{[5]} \\
{[2]} \\
{[2]} \\
{[5]}\end{array}$ \\
\hline
\end{tabular}

a The value was calculated from that originally given for a slightly different concentration on the assumption that the ratio of the $E E$ for cellobiose to that for celtrobiose is the same at the 2 concentrations.

$b$ Calculated according to the same method as for celtrobiose, using lactose as standard.

$c$ These values have been determined in the present investigation.

The pronounced effects of even slight changes in the aglucon are very evident. Thus, cellobiose and 4 - $\beta$-glucosidomannose differ only in the configuration of one carbon atom, and yet this change from the glucose to the mannose configuration produces a very marked decrease in the rate of the enzymatic cleavage. Similarly, $4-\beta$-glucosido- $d$-mannose and celtrobiose differ only in the configuration of the third carbon of the aglucon sugar, and yet the EE values of the sugars are in the ratio 1:10. A change in the position of the glucosidic bridge from the fourth carbon of the aglucon sugar (cellobiose) to the sixth carbon atom (gentiobiose) with no other changes in configuration or structure reduces the rate of hydrolysis about one-half. For the $\beta$-galactosides, corresponding differences may be observed. It is of interest to note for these compounds the effect of breaking the pyranose ring of the aglucon by reduction of the glucose group to the sorbito] group or gluconic acid group. The $E E$ values for lactobionic acid and lactositol are approximately one-tenth to one-twentieth of the values for lactose. As was previously shown, lactulose which probably has fructofuranose [7] as the aglucon sugar is slightly more rapidly hydrolyzed than lactose which has glucose as the aglucon sugar [2].

The magnitude of the effect of small changes in the configuration or structure on the rate of enzymatic hydrolysis may appear to be difficult to explain. However, if we assume, ${ }^{2}$ as suggested by Euler [9], that the enzyme adsorbs the substrate material at two positions and not merely at one, as assumed by Weidenhagen and other workers [1], the results are explainable. If each of the hydroxyl groups of the aglucon potentially is adsorbable by the enzyme when steric conditions are favorable, then the change of configuration of one carbon atom of the aglucon sugar would undoubtedly influence the number of adsorption

2 The suggestion of Euler [9] that the action of enzymes involves an intermediate adsorption of substrate and enzyme at two positions has been criticized by Weidenhagen [1] but otherwise has not received mueh attention. It seems to the writer, however, that such a mechanism is not in contradiction to the Weidenhagen theory [1] or to the modified form previously suggested [10], but instead, the "two affinity theory" is capable of explaining many of the difficulties of the original Weidenhagen theory. At the present time it seems that Euler's concept, when extended and made more specific, provides a logical explanation for the known reactions and properties of the glycosidases and possibly of other enzymes. Additional experimental work is being carried out in order to test the validity of this mechanism. 
bonds which the aglucon can form with the enzyme. This effect would, however, be much greater than the loss or gain of one linkage, since the change of configuration of one carbon simultaneously would affect the conformation of the entire aglucon group. The various hexose sugars differ in that the different configurations of the carbons of the pyranose ring produce different conformations of the ring as a whole, depending upon the spatial distribution and proximity of the hydroxyl groups [11]. Because of this effect on the conformation of the pyranose ring produced by the change in configuration of even a single carbon atom or by a change in the position or nature of substituent groups, changes in the configuration or structure of a disaccharide aglucon group would undoubtedly produce an effect on the agluconenzyme complex much greater than that produced by the loss of a single adsorption bond.

The slow rate of hydrolysis of lactositol and of lactobionic acid is more difficult to understand, since the breaking of the pyranose ring produced by reduction changes the aglucon from a cyclic structure to a branched-chain methylpentanol derivative. The branched chain should be more easily accommodated to the adsorbing atoms of the active centers of the enzyme than a similar cyclic structure. For this reason, it would seem that the lactositol should be more easily hydrolyzed than either lactose or phenyl $\beta$-galactoside, but actually thelactose is cleaved about 13 times and the phenyl $\beta$-galactoside about 60 times as rapidly as the lactositol under the conditions employed. Although it would be supposed that lactositol is adsorbed well, the rate of hydrolysis isslow. The following considerations indicate, however, that this apparent anomaly is not necessarily in contradiction with the above explanations, which are based on the postulate that ordinarily high adsorption results in rapid enzymatic hydrolysis. For a series of glucosides or galactosides of similar type, the adsorption of the aglucon increases (1) as the number of atoms capable of adsorption is made greater or (2) as the new groups have greater adsorptive power than those replaced. The results obtained with the lactositol would, however, indicate that for such a series having aglucon groups of increasing adsorptive power, the rate of hydrolysis increases at first, reaches a maximum, and then decreases. For the series $\mathrm{CH}_{2} \mathrm{OH}-$ $(\mathrm{CHOH})_{n}-\mathrm{CH}_{2}-\mathrm{O}$-glucoside (where $n$ increases from zero to an indefinitely large number) it would seem that the rate of hydrolysis by the enzyme should reach a maximum at some intermediate value of $n$ and then decrease as the chain is lengthened.

The substituted-phenyl $\beta$-glucosides or galactosides probably constitute a series for which the increase of adsorption is dependent on the adsorptive powers of the substituent groups, although the electronic effects of these groups probably cannot be completely disregarded. The enzymatic hydrolysis of the substituted-phenyl $\beta$-glucosides has been studied for a large number of compounds by Helferich and coworkers $[12,13,14]$. Of the compounds studied, Helferich reports that all having groups in the ortho position are more easily hydrolyzed than the unsubstituted phenyl $\beta$-glucoside except the $0-\mathrm{NH}_{2}-\mathrm{CH}_{2}$-phenyl $\beta$-glucoside. The galactosides, although not so well studied, behave similarly. But from the results of Myrbäch's work [15] on the action of amines on invertase, it would be expected that the amino group would be readily adsorbed on the enzyme surface and even possibly form compounds of the Schiff 
base type with carbonyl groups in the active adsorbing area. The results reported for the aminophenyl glycosides are then in agreement with those reported for lactositol in that in both cases while the aglucon is probably highly adsorbed the rate of hydrolysis is slow.

The following mechanism for the enzymatic hydrolysis of a glycoside is advanced to explain this apparently unusual combination of high adsorption of the glucoside and slow rate of hydrolysis. At the same time it appears to be in qualitative agreement with most of the data obtained by other investigators in this field.

(1)

Enzyme

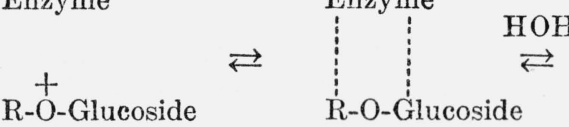

(2)

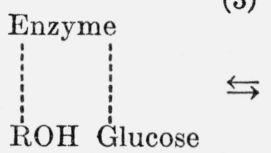

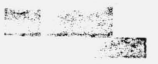

Enzyme+ $\mathrm{ROH}+$

In the above equations, the dotted lines represent adsorption forces which may be hydrogen bonds or Van der Waals forces. There may be one or more for the aglucon group and for the glucoside group. The number of bonds depends on the number of atoms in the glucoside (including the aglucon) capable of forming such bonds and also on the arrangement of the bond-forming atoms of the active areas of the enzyme. Ordinarily reaction (1) or (2) is the rate-determining reaction, but when the aglucon is highly adsorbed, the ROH-enzymeglucose compound dissociates slowly and the rate-determining reaction seems to be reaction (3). This mechanism will be developed further in later publications.

In table 2 are listed the $E E$ values (enzyme efficiency) for the $p$-chloro-, $p$-bromo- and $p$-iodosalicins. The three substances are hydrolyzed at approximately the same rates, but the $E E$ values are in the order: iodosalicin > bromosalicin >chlorosalicin. All three substances are more slowly hydrolyzed than salicin. The substitution of a halogen atom into the para position of salicin lowers the rate of hydrolysis.

TABLE 2.-Summary of action of almond emulsin on halogenosalicins

\begin{tabular}{|c|c|c|c|}
\hline Substrate & $\begin{array}{l}\text { Structure of } \\
\text { glucoside }\end{array}$ & $\begin{array}{l}\text { Enzyme } \\
\text { efficiency } \\
(E E)\end{array}$ & $\begin{array}{c}E E \\
\text { (dilute con- } \\
\text { centration) }\end{array}$ \\
\hline $\begin{array}{l}\text { Salicin } \\
p \text {-Chlorosalicin } \\
p \text {-Bromosalicin } \\
p \text {-Iodosalicin }\end{array}$ & $\begin{array}{l}X=\mathrm{H} \\
X=\mathrm{Cl} \\
X=\mathrm{Br} \\
X=\mathrm{I}\end{array}$ & $\begin{array}{l}2.0 \\
0.48 \\
.60 \\
(.62)\end{array}$ & $\begin{array}{l}2.9 \\
0.99 \\
-1.24\end{array}$ \\
\hline
\end{tabular}

\section{EXPERIMENTAL PROCEDURE}

\section{SUBSTRATES AND SUBSTRATE SOLUTIONS}

In general, the substrate concentrations in the reaction mixture were the same as those ordinarily used by Helferich $(0.052 M)$. Since the $p$-iodosalicin is too insoluble for the customary concentration to be used, the measurements were made on solutions of half the normal concentration. The rotations and concentrations of the disaccharides used are given in table 3 . The salicin derivatives had the rotations previously reported by $\mathrm{D}$. H. Brauns [6]. 
TABLE 3.-Optical rotation and concentration of disaccharides used in the investigation

\begin{tabular}{|c|c|c|}
\hline Compound & {$[\alpha]_{D}^{20}$} & $\begin{array}{l}\text { Grams of } \\
\text { substrate in } \\
25 \text { ml buffer } \\
\text { solution }\end{array}$ \\
\hline $\begin{array}{l}\text { Lactose } . \mathrm{H}_{2} \mathrm{O} \\
4-\beta \text {-glucosido- } d \text {-mannose } \cdot \mathrm{H}_{2} \mathrm{O} \\
\text { Cellobiose } \cdot \mathrm{H}_{2} \mathrm{O} \\
\text { Gentiobiose } \\
\text { Lactositol } .2 \mathrm{H}_{2} \mathrm{O}_{-}\end{array}$ & $\begin{array}{r}52.6 \\
5.2 \\
34.8 \\
9.7 \\
13.3\end{array}$ & $\begin{array}{l}0.703 \\
.704 \\
.703 \\
.668 \\
.743\end{array}$ \\
\hline
\end{tabular}

The concentrations given in table 3 are not the concentration in the reaction mixture but of a stronger solution which was later diluted with enzyme solution in the ratio of 2 volumes of substrate solution plus 1 volume of enzyme solution. The quantities indicated in the table 3 were made up to a volume of $25 \mathrm{ml}$ with Walpole $0.2-M$ acetate buffer ( $\mathrm{pH} 5.0$ at $18^{\circ}$ C.).

\section{ENZYME SOLUTIONS}

The enzyme solutions were made up as previously described [16] from a sample of almond emulsin (Rohferment) furnished by the courtesy of B. Helferich. The material had a $\beta$-glucosidase value [17] of 1.0. For the enzyme concentrations, see tables 4 and 5 .

\section{RATE OF HYDROLYSIS MEASUREMENTS}

The details of the method used have been previously described [16]. For salicin and the halogenosalicins, the rate of hydrolysis was determined polarimetrically. To $2 \mathrm{ml}$ of the buffered substrate solution there was added $1 \mathrm{ml}$ of the enzyme solution. After $t$ minutes at $30^{\circ} \mathrm{C}$, the reaction was stopped by the addition of $0.2 \mathrm{~g}$ of potassium carbonate, and after about 1 hour the solution was read in a $2-\mathrm{dm}$ tube at $20^{\circ} \mathrm{C}$. For the experimental results, see table 4.

TABLE 4.-Enzymatic hydrolysis of halogenated salicin

[ $T=30^{\circ} \mathrm{C} ; \mathrm{pH}=5.0 ; g=0.0240 \mathrm{~g}$ of enzyme in $50 \mathrm{ml}$ of reaction mixture]

\begin{tabular}{|c|c|c|c|c|c|c|c|c|c|c|c|}
\hline$\underset{(\min )}{\text { Time, } t}$ & $\begin{array}{c}{ }^{\circ} \mathrm{S} a \\
\text { after } \\
t \\
\text { min }\end{array}$ & $\begin{array}{c}\text { Hydrol- } \\
\text { ysis } \\
\text { (per- } \\
\text { cent) }\end{array}$ & ${ }^{b} k \times 10^{4}$ & $\begin{array}{l}\text { Sub- } \\
\text { strate } \\
\text { concen- } \\
\text { tration } \\
(M)\end{array}$ & $E E$ & $\underset{\text { (min) }}{\text { Time, } t}$ & $\begin{array}{c}{ }^{\circ} \mathrm{S} a \\
\text { after } \\
t \\
\min \end{array}$ & $\begin{array}{c}\text { Hydrol- } \\
\text { ysis } \\
\text { (per- } \\
\text { cent) }\end{array}$ & ${ }^{b} k \times 10^{4}$ & $\begin{array}{l}\text { Sub- } \\
\text { strate } \\
\text { concen- } \\
\text { tration } \\
(M)\end{array}$ & $E E$ \\
\hline \multicolumn{6}{|c|}{ SALICIN } & \multicolumn{6}{|c|}{ CHLOROSALICIN } \\
\hline 0 & -5.76 & & & & & 0 & -6.48 & & & & \\
\hline 10 & -3.42 & 27.2 & 138 & 0.052 & 1. 91 & 30.0 & -4.36 & 22.8 & 34.1 & 0.052 & 0.48 \\
\hline 12 & $\begin{array}{l}-3.09 \\
-2.08\end{array}$ & 31.0 & 135 & .052 & 1. 87 & \multirow{2}{*}{$\infty$} & \multirow{2}{*}{$\begin{array}{r} \\
+2.83 \\
\end{array}$} & 27.2 & 34.4 & .052 & .47 \\
\hline \multirow{2}{*}{15} & -2.08 & 42.7 & & .052 & 2.23 & & & & & Avg... & \multirow[t]{2}{*}{0.48} \\
\hline & +2.83 & - & $\ldots$ & Avg & 2.0 & \multirow{3}{*}{$\begin{array}{c}0 \\
20.0 \\
40.3\end{array}$} & \multirow{2}{*}{$\begin{array}{l}-3.29 \\
-1.81\end{array}$} & & & & \\
\hline \multirow{3}{*}{$\begin{array}{c}0 \\
9.0 \\
10.0\end{array}$} & -2.87 & & & & & & & \multirow{4}{*}{$\begin{array}{l}31.4 \\
43.3\end{array}$} & \multirow{4}{*}{$\begin{array}{l}81.9 \\
61.2\end{array}$} & \multirow{4}{*}{$\begin{array}{r}.026 \\
.026 \\
\text { Avg }\end{array}$} & \multirow{4}{*}{$\begin{array}{l}1.13 \\
0.85 \\
0.99\end{array}$} \\
\hline & -1.38 & 34.7 & 206 & .026 & 2. 85 & & -1.25 & & & & \\
\hline & -1.21 & 38.7 & 213 & .026 & 2.94 & & \multirow{2}{*}{+1.42} & & & & \\
\hline \multirow[t]{2}{*}{$\infty$} & +1.42 & & & Avg. & 2.9 & & & & & & \\
\hline & & & & & & \multicolumn{6}{|c|}{ IODOSALICIN } \\
\hline \multicolumn{6}{|c|}{ BROMOSALICIN } & \multirow{5}{*}{$\begin{array}{l}0 \\
20.4 \\
41.0 \\
\\
\infty\end{array}$} & \multirow{5}{*}{$\begin{array}{l}-3.39 \\
-1.55 \\
-0.92 \\
+1.42\end{array}$} & & \multirow{5}{*}{$\begin{array}{r}103 \\
76\end{array}$} & \multirow{5}{*}{$\begin{array}{r}0.026 \\
.026 \\
\text { Avg } \\
\end{array}$} & \multirow{3}{*}{$\begin{array}{l}1.42 \\
1.06\end{array}$} \\
\hline 0 & -6.90 & & & & & & & 38.3 & & & \\
\hline 30.1 & -4.15 & 28.3 & 47. 9 & 0.052 & 0.66 & & & 51.4 & & & \\
\hline & & 31.2 & 39.3 & & & & & & & & 1. 24 \\
\hline$\infty$ & +2.83 & & & Avg & 0.60 & & & & & & \\
\hline
\end{tabular}

a Measured in 2-dm tube with a Bates saccharimeter. A small correction for the rotation of enzyme $(-0.17)$ has been made.

$b$ Common logarithms. 
TABLE 5.-Enzymatic hydrolysis of disaccharides

$\left[T=30.0^{\circ} \mathrm{C} ; \mathrm{pH}=5.0\right]$

\begin{tabular}{|c|c|c|c|c|c|c|}
\hline $\begin{array}{l}\text { Time } \\
(\min )\end{array}$ & $\begin{array}{l}0.1 \mathrm{~N}^{a} \mathrm{I}_{2} \\
\text { used (ml) }\end{array}$ & $\begin{array}{l}\mathrm{I}_{2} \text { used, cor- } \\
\text { rected }^{b}(\mathrm{ml})\end{array}$ & $\begin{array}{c}\text { Hydrolysis } \\
\text { (percent) }\end{array}$ & • $k \times 10^{5}$ & $g^{d}$ & e $E E \times 10^{3}$ \\
\hline \multicolumn{7}{|c|}{ LACTOSE } \\
\hline $\begin{array}{l}0 \\
104.5 \\
157.2 \\
236\end{array}$ & $\begin{array}{l}10.59 \\
16.06 \\
17.08 \\
18.42\end{array}$ & $\begin{array}{l}0 \\
2.26 \\
3.28 \\
4.62\end{array}$ & $\begin{array}{l}21.3 \\
31.0 \\
43.6\end{array}$ & $\begin{array}{l}100 \\
103 \\
105\end{array}$ & $\begin{array}{r}0.3053 \\
.3053 \\
.3053\end{array}$ & $\begin{array}{l}10.9 \\
11.2 \\
11.4\end{array}$ \\
\hline$\infty$ & - & $(10.59)$ & $(100)$ & - & Avg & 11.2 \\
\hline \multicolumn{7}{|c|}{ 4- $\beta$-GLUCOSIDO- $d$-MANNOSE } \\
\hline $\begin{array}{c}0 \\
1,596 \\
1,685\end{array}$ & $\begin{array}{r}9.61 \\
17.47 \\
18.18\end{array}$ & $\begin{array}{l}0 \\
4.97 \\
5.68\end{array}$ & $\begin{array}{l}51.7 \\
59.1\end{array}$ & $\begin{array}{l}19.8 \\
23.0\end{array}$ & $\begin{array}{c}0.3053 \\
.3053\end{array}$ & $\begin{array}{l}2.15 \\
2.50\end{array}$ \\
\hline$\infty$ & - n & $(9.61)$ & $(100)$ & -.....- & Avg & 2.33 \\
\hline \multicolumn{7}{|c|}{ GENTIOBIOSE $f$} \\
\hline $\begin{array}{c}0 \\
75.0 \\
125.3\end{array}$ & $\begin{array}{l}10.00 \\
15.08 \\
16.66\end{array}$ & $\begin{array}{l}0 \\
3.80 \\
5.38\end{array}$ & $\begin{array}{c}0 \\
38.0 \\
53.8\end{array}$ & $\begin{array}{l}277 \\
268\end{array}$ & $\begin{array}{c}0.1204 \\
.1204\end{array}$ & $\begin{array}{l}76.4 \\
74.0\end{array}$ \\
\hline$\infty$ & - & $(10.00)$ & $(100)$ & (n..... & Avg & 75.2 \\
\hline \multicolumn{7}{|c|}{ CELLOBIOSE } \\
\hline $\begin{array}{l}0 \\
20.0 \\
33.0 \\
60.3\end{array}$ & $\begin{array}{r}9.67 \\
13.42 \\
14.36 \\
16.68\end{array}$ & $\begin{array}{l}0 \\
2.26 \\
3.20 \\
5.52\end{array}$ & $\begin{array}{l}23.4 \\
33.1 \\
57.1\end{array}$ & $\begin{array}{l}579 \\
529 \\
610\end{array}$ & $\begin{array}{r}0.1198 \\
.1198 \\
.1198\end{array}$ & $\begin{array}{l}161 \\
147 \\
169\end{array}$ \\
\hline$\propto$ & 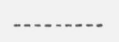 & $(9.67)$ & $(100)$ & -...... & Avg & 159 \\
\hline \multicolumn{7}{|c|}{ LACTOSITOL } \\
\hline $\begin{array}{c}0 \\
1,580 \\
3,010 \\
4,540\end{array}$ & $\begin{array}{l}0.59 \\
6.58 \\
7.93 \\
9.39\end{array}$ & $\begin{array}{l}0 \\
2.78 \\
4.13 \\
5.59\end{array}$ & $\begin{array}{l}26.7 \\
39.7 \\
53.7\end{array}$ & $\begin{array}{l}8.5 \\
7.3 \\
7.4\end{array}$ & $\begin{array}{r}0.3053 \\
.3053 \\
.3053\end{array}$ & $\begin{array}{c}0.92 \\
.79 \\
.81\end{array}$ \\
\hline$\infty$ & - & $(10.41)$ & $(100)$ & - & Avg & 0.84 \\
\hline
\end{tabular}

a The volume of the reaction solution was $10 \mathrm{ml}$ for the lactose, gentiobiose, and lactositol experiments and $9 \mathrm{ml}$ for the others.

$b$ This column gives the value after correction for the amount of iodine absorption by the amount of sugar initially present (the value at zero time) and for the amount of iodine absorbed by the enzyme under similar conditions. For the lactose and lactositol, $3.33 \mathrm{ml}$ of enzyme solution required $3.21 \mathrm{ml}$ of $0.1 \mathrm{~N}$ iodine; for the $4-\beta$ - glucosido- $d$-mannose experiments, $3 \mathrm{ml}$ of enzyme required $2.89 \mathrm{ml}$; for the cellobiose experiments, $3 \mathrm{ml}$ required $1.49 \mathrm{ml}$; and for the gentiobiose experiments, $3.33 \mathrm{ml}$ of enzyme solution required $1.28 \mathrm{ml}$ of $0.1 \mathrm{~N}$ iodine.

$c$ Calculated, using common logarithms.

d Grams of enzyme in $50 \mathrm{ml}$ of reaction mixture.

- Enzyme efficiency, or Wertigkeit. $E E=k /(g \times \log 2)$.

$f$ For gentiobiose, the slightly low initial value indicates that the material was not entirely free from methyl alcohol. Gentiobiose crystallizes from methyl alcohol with 2 moles of methyl alcohol. This alcohol of crystallization is lost very easily by keeping the compound in a desiccator over calcium chloride.

The hydrolysis of the disaccharides was measured by determining the aldose sugar present at any time by Helferich's modification of Cajori's iodometric method [16]. Since the reaction takes place stoichiometrically, the amount of iodine required for 100-percent hydrolysis would be twice that for the original disaccharide. The experimental results are given in table 5 . 
The methods used for making the calculations are given in another place [16]. Toluene was added to all experiments to prevent the growth of microorganisms.

\section{REFERENCES}

[1] R. Weidenhagen, Ergeb. Enzymforsch. 1, 168 (1932).

[2] B. Helferich and W. W. Pigman, Ber. deut. chem. Ges. 72, 212 (1939).

[3] B. Helferich, R. Gootz and G. Sparmberg, Z. physiol. Chem. 261, 189 (1939).

[4] N. K. Richtmyer and C. S. Hudson, J. Am. Chem. Soc. 61, 1834 (1939).

[5] B. Helferich, W. W. Pigman and H. S. Isbell, Z. physiol. Chem. 261, 189 (1939).

[6] D. H. Brauns, J. Am. Chem. Soc. 47, 1285 (1925).

[7] H. S. Isbell and W. W. Pigman, J. Research N BS 20, 773 (1938); RP1104.

[8] S. R. Petersen, Ber. Verhandl. sächs. Akad. Wiss. Leipzig, Math. phys. Klasse 85, 154 (1933).

[9] H. v. Euler, Z. physiol. Chem. 143, 79 (1925).

[10] W. W. Pigman, J. Am. Chem. Soc. 62, 1371 (1940).

[11] H. S. Isbell and W. W. Pigman, J. Research NBS 18, 141 (1937) RP969; H. S. Isbell, J. Research NBS 18, 505 (1937) RP990; H. S. Isbell and H. L. Frush, J. Research NBS 24, 125 (1940) RP1274.

[12] B. Helferich, H. Scheiber, R. Streeck and F. Vorsatz, Liebigs Ann. Chem. 518, 211 (1935).

[13] B. Helferich, Ergeb. Enzymforsch. \%, 83 (1938).

[14] B. Helferich, E. Günther and S. Winkler, Liebigs Ann. Chem. 508, 192 (1933).

[15] K. Myrbäch, Z. physiol. Chem. 158, 161 (1926) (see particularly p. 263, 264, 274).

[16] W. W. Pigman, J. Research NBS 26, 197 (1941) RP1369.

[17] R. Weidenhagen, Z. Ver. Zucker-Ind. \%9, 591 (1929).

[18] B. Helferich and W. Göller, Z. physiol. Chem. 247, 220 (1937).

Washington, May 2, 1941. 